\title{
LTA4H wt Allele
}

National Cancer Institute

\section{Source}

National Cancer Institute. LTA4H wt Allele. NCI Thesaurus. Code C116950.

Human LTA4H wild-type allele is located in the vicinity of $12 \mathrm{q} 22$ and is approximately 43

$\mathrm{kb}$ in length. This allele, which encodes leukotriene A-4 hydrolase, is involved in the biosynthesis of leukotriene B4. 